\title{
The Relationship between Housing Finance and Macroeconomics Variables in Malaysia
}

\author{
${ }^{1}$ Nur Baizura Binti Mohd Shukor, ${ }^{2} \mathrm{Dr}$ Sr Rosli Bin Said and ${ }^{3} \mathrm{Dr}$ Rohayu Bin Abdul Majid \\ ${ }^{1}$ Department of Estate Management, Faculty of Architecture, Planning \& Surveying, University Teknologi MARA, Seri Iskandar Campus, Seri \\ Iskandar, 32610 Perak \\ ${ }^{2}$ Department of Estate Management, Faculty of Built Environment, University Malaya, 50603 Kuala Lumpur \\ ${ }^{3}$ Department of Estate Management, Faculty of Architecture, Planning \& Surveying, University Teknologi MARA, 40450 Shah Alam, Selangor
}

\begin{abstract}
Housing finance is one of the factors that contribute in the overall economy growth of the country. The purpose of this paper is to analyse the relationship of housing finance variable and the macroeconomic variables in Malaysia. By adopting time series technique of Vector Auto regression (VAR) and Impulse Response to determine the dynamic relationship between the macroeconomic and housing finance variable. The cointegration result shows that there exists a long run relationship between the macroeconomic variable and housing finance variable. The finding from impulse response function indicates that Gross Domestic Product (GDP) response positively to the Primary Mortgage Market (PMM), which shows that during the good economy there are more housing loan extends by the banking institution. Meanwhile, interest rate response negatively to Secondary Mortgage Market (SMM), which implies that during the financial crisis, more housing loan sold to the Secondary Mortgage Market as one of the measure by the government to increase liquidity in banking institutions. As a conclusion, there is presence of relationship between the variable which change in one variable will affect the other variable in the long run.
\end{abstract}

\section{Introduction}

Housing finance is defined as a system of money and credit that enables all types of housing to be built, improved, bought, rented, maintained and repaired (Garnett, 2005). Housing finance system is different between each country based on the country direction, policy and lending guideline implemented in each country. The role of housing finance in Malaysia is to provide financing property development for the developers, as well as provide end financing to the homebuyers to buy a house. The Asian Financial Crisis in 1997 and Global Financial Crisis in 2008 had brought significant effects in the Asian countries including Malaysia. Real output, manufacturing and trade investment growth rate decrease due to the falling demand in economic development. The real GDP is an accurate macroeconomic indicator in measuring the productivity of a country. The financial crisis affected the Malaysian housing market, as well as the housing finance.

Previous research had focused on the relationship between macroeconomic, financial and bank credit variables. They findings showed that there is a relationship between bank lending with macroeconomic variables (for example real GDP and interest rate), asset prices (for instance house and stock prices), or investigated its relationship to macroeconomic uncertainty. Mansor and Mohamed (2012) studied the relationship between bank credit, macroeconomic variable and financial uncertainty in Malaysia. By using the vector autoregressions (VARs) approach to test the cointegration and causality, they finding showed that real domestic output have a positive and long-run relationship with bank credit and stock price. For short-run dynamic analysis, they found that interest rate shock gives a negative response to real output, real bank credits, and stock prices.

Another research by Gerlach and Peng (2005) using the same approach of VAR, had investigated dynamics relationship between property prices and bank lending in Hong Kong with four variables, which are GDP, interest rate, property prices and bank lending. They findings showed there is a correlation between property price and bank lending. The relationship showed that bank lending adjusted property prices rather than the opposite. Their finding showed that bank lending is one of the main factors in adjusting the house price. Therefore, housing finance is one of the tool to improve the country economy during the downturn and during the recovery period housing finance function as a tool to regulate the country economy. The problem statement mentioned above has brought out the research question of what are the 
relationships between macroeconomic and housing finance variables in Malaysia.

\section{Literature Review}

\subsection{Housing Finance System}

Housing finance is defined as a system of money and credit that enables all types of housing to be built, improved, bought, rented, maintained and repaired (Garnett, 2005). Based on the basic concept of housing finance system, bank or any other financial institution acts as a financial intermediary, which takes deposit from the surplus agent (savers) then lends the money to the deficit agent (borrowers) who needs money to purchase house. Housing finance system is different between each country based on the country direction, policy and lending guideline implemented in each country. Among the Asian countries, Malaysia showed the highest ratio of housing finance with Gross Domestic Product (GDP), with the housing finance at 32 percent of GDP compared to the Philippines, which showed the ratio on housing finance at about 12 percent of GDP. A study by Veronica (2008) on the housing finance system in emerging countries concluded that countries with strong legal right to the lenders and borrowers, deeper credit information system and more stable macroeconomic environment would have better housing finance system.

The relationship between bank lending and property price gets much attention among scholars recently. If the banks strengthen their lending policies, this will affect the homebuyer eligibility to get the financing and directly will decrease the demand to purchase a house. Therefore, this will slow down the housing market activities and indirectly will influence the property price. For countries that are denominated by the bank-oriented system, the housing finance system will be affected if there are any changes to the bank lending policy. Few of previous study have shown that changes in bank lending policy will affect the housing finance system for that country (Greef and Haas, 2000; Hilbers et al., 2001). A study was conducted by Gerlach and Peng (2005) on the relationship between property price and bank lending in Hong Kong to determine if any adjustment made to the bank lending will affect the property price instead of the opposite. Their finding showed that bank lending is the main factor in adjusting the house price. In the local context, Mansor and Mohamed (2012) found that there is a positive relation between real GDP and both real stock price and real bank credit in the long run. Meanwhile, the finding on a short-run analysis shows that the interest rate shock will give a negative response to real output, real bank credits and stock prices.

Housing finance is one of the factors that contribute in the overall economy growth of the country. The role of housing finance as a tool to boost the housing market is proven, especially during the financial crisis. The relationship between housing finance and housing market is dependent on each other. Expansion in the housing market means that there are more house buyers require financing. A strong housing finance will definitely give a positive impact to the country's economy. Housing finance is one of the most essential medium in the housing delivery framework, which shapes housing delivery system in most countries (Tiwari, 2000).

The research by Said et al. (2014) analyzed the relationship between the housing market and housing finance system. The analysis showed that there is a relationship between the primary market and the housing market. Meanwhile, there is no relationship between the housing market and the secondary market, as well as the capital market. Apart from that, the analysis showed the relationship between the three housing finance sub-markets. Any changes to the Primary Mortgage Market (PMM) will affect the Capital Market (CM), where any changes to the Secondary Mortgage Market (SMM) will not affect the Capital Market (CM).

\subsection{Malaysia Housing Finance}

The primary mortgage market (PMM) in Malaysia is dominated by the housing credit institution (HCI). The role of the housing credit institution is to provide either bridging or project finance to the developer constructing the house or end financing to the house purchasers. The developers apply for bridging loan to ease their cash flow during the construction period while waiting for pending payment from end purchaser or their end financier. The utilization of bridging loan is controlled by the bank, where fund will be released progressively against the architect certificate of the work done. Meanwhile, for home buyers, they need end-financing as a source of fund to buy a house, since buying a house is one of the large consumptions by the consumer. Seven main players in housing credit institution are commercial banks, Treasury Housing Loan Division, Bank Kerjasama Rakyat Malaysia Berhad, Malaysia Building Society Berhad, Borneo Housing Mortgage Berhad, Bank Simpanan Nasional Berhad and Sabah Credit Cooperation.

National Mortgage Corporation Cagamas is the only entity that operates the Secondary Mortgage Market (SMM) in Malaysia. The role of Cagamas is to support the wider spread of home ownership and develop of the securitization market in Malaysia (Chung, 2014).The establishment of Cagamas comes from the result of the liquidity crunch in the 1980s, where there was a funding mismatch in financial institutions. Therefore, an intermediary party is needed between the primary lenders and investors for the long term fund. A primary lender sells their housing loan to Cagamas and issues private debt securities to finance the purchase of the original housing loan. By buying the housing loan from the originator, this allows the originator to give more loans to other people and will indirectly increase their liquidity and lower their interest rate risk. Cagamas issues bonds/sukuk to finance the purchase of mortgage from financial and non-financial institutions.

The Malaysian Capital Market is regulated by the Kuala Lumpur Stock Exchange (KLSE), and the performance of this market can be measured using the Kuala Lumpur Composite Index (KLCI). The Malaysian Primary Mortgage Market originates pools of housing funds. These pools of fund are 
being sold to Cagamas (Secondary Mortgage Market) and securitized in the Malaysian Capital Market by issuing the Private Debt Securities (PDS).

\section{Data And Methodology}

\subsection{Data transformation}

The problem of heteroscedasticity in presenting a model can be solved by transforming the independent and dependent variables into the $\log$ form. By transforming the variable into the $\log$ form, this can result in the reduction of the heteroscedasticity because the scale of the variable is being compressed. The natural logarithm basis is $\log _{\mathrm{e}}(\mathrm{A})=\ln (\mathrm{A})$ (Koop 2008). The transformation of data into natural logarithm is the appropriate approach in dealing with the nonstationary variable in the time series

The macroeconomic variable and the housing finance variable were transformed into the natural logarithm. The natural $\operatorname{logarithm}$ basis is $\log _{\mathrm{e}}(\mathrm{A})=\ln (\mathrm{A})$. All variables had been transformed into natural logarithm except for the Base Lending Rate (BLR). Table 1 shows the transformed logarithm of data and the new symbol to represent the data after transformation.

Table 1 Transformation of variables

\begin{tabular}{|c|c|c|c|c|}
\hline $\begin{array}{c}\text { Varia } \\
\text { ble }\end{array}$ & Sub-group & Data & $\begin{array}{c}\text { Transfor } \\
\text { med } \\
\text { variable }\end{array}$ & $\begin{array}{l}\text { Symbol } \\
\text { after } \\
\text { transforma } \\
\text { tion }\end{array}$ \\
\hline GDP & $\begin{array}{c}\text { Macroecon } \\
\text { omic } \\
\text { variable }\end{array}$ & $\begin{array}{c}\text { Gross } \\
\text { Domesti } \\
\text { c } \\
\text { Product } \\
\text { (million } \\
\text { ) }\end{array}$ & $\begin{array}{l}\text { Nat.log } \\
\text { of GDP }\end{array}$ & LGDP \\
\hline BLR & $\begin{array}{c}\text { Macroecon } \\
\text { omic } \\
\text { variable }\end{array}$ & $\begin{array}{c}\text { Average } \\
\text { base } \\
\text { lending } \\
\text { rate by } \\
\text { commer } \\
\text { cial } \\
\text { bank } \\
(\%)\end{array}$ & - & BLR \\
\hline PM & $\begin{array}{c}\text { Primary } \\
\text { mortgage } \\
\text { market }\end{array}$ & $\begin{array}{c}\text { Total } \\
\text { housing } \\
\text { loan by } \\
\text { commer } \\
\text { cial } \\
\text { bank }\end{array}$ & $\begin{array}{c}\text { Nat.log } \\
\text { of PM }\end{array}$ & LPM \\
\hline SM & $\begin{array}{c}\text { Secondary } \\
\text { mortgage } \\
\text { market }\end{array}$ & $\begin{array}{c}\text { Total } \\
\text { housing } \\
\text { loan } \\
\text { sold to }\end{array}$ & $\begin{array}{c}\text { Nat.log } \\
\text { of SM }\end{array}$ & LSM \\
\hline
\end{tabular}

\begin{tabular}{|c|c|c|l|l|}
\hline & & $\begin{array}{c}\text { Cagama } \\
\text { s }\end{array}$ & & \\
\hline
\end{tabular}

\subsection{Unit root test}

Several studies have shown that differencing non stationary time series before estimation does not adequately account for the long-run relationship. The assumptions on stationary simply means every series, mean, variance and covariance does not change over time. By that there is clear consensus where there is a need to examine the stochastic property of series used in the analysis before applying formal test for cointegration and causation. To eliminate the possibility of spurious regression, the unit root test is performed on the variable.

The integration of the variable shows how many times they have been differenced to be stationary. Integrated of order one I(1) indicate that such variable have been differenced once in order to achieve stationary. Similar to I(2), it is integrated at the second order which indicates that such variable have been differenced twice in order to achieve stationary. The unit root test chosen was the Augmented Dickey and Fuller (ADF) tests. To find the optimum lag for each variable, the Akakike Information Criterion (AIC) and the Schwarz Information Criteria (SIC) were selected. If the variables are all stationary at the same level, then the cointegration test will be applied to examine their long-run relationship

Table 2 shows the result of the unit root test on level with intercept and trend for all variables. The results show that all variables are in $\mathrm{I}(1)$ condition, where all the variables have unit roots and failed to reject the null hypothesis that all variables have unit roots. Therefore, all variables need to be differentiated in order to make it stationary.

Table 2 ADF Test on Level (Intercept and Trend)

\begin{tabular}{|l|c|c|c|c|}
\hline Symbol & t-statistic & Probability & $\begin{array}{c}5 \% \\
\text { critical } \\
\text { value }\end{array}$ & $\begin{array}{c}\text { Unit } \\
\text { root }\end{array}$ \\
\hline LGDP & -2.553580 & 0.3024 & -3.478305 & $\mathrm{I}(1)$ \\
\hline LPM & -1.606753 & 0.7800 & -3.478305 & $\mathrm{I}(1)$ \\
\hline LSM & -2.226831 & 0.4671 & -3.478305 & $\mathrm{I}(1)$ \\
\hline LBLR & -2.236656 & 0.4616 & -3.480463 & $\mathrm{I}(1)$ \\
\hline
\end{tabular}

The results for the unit root test on 1st difference with intercept and trend for all variables are shown in Table 3. The results show that all variables are stationary in first difference, where it is to be integrated of order 1 . The results show that the t-statistics values are smaller than the $5 \%$ critical values, and the probability value is less than $5 \%$. Therefore, the null 
hypothesis can be rejected where all variables have unit root. Unit root test using the ADF approach showed that all the variables are non-stationary in level but the variables are stationary in the first difference. In order to perform a cointegration test, all the variables need to be stationary at the same level.

Table 3 ADF Test on $1^{\text {st }}$ difference (Intercept and Trend)

\begin{tabular}{|l|c|c|c|c|}
\hline Symbol & t-statistic & Probability & $\begin{array}{c}5 \% \\
\text { critical } \\
\text { value }\end{array}$ & $\begin{array}{c}\text { Unit } \\
\text { root }\end{array}$ \\
\hline LGDP & -7.375788 & 0.0000 & -3.480463 & $\mathrm{I}(0)$ \\
\hline LPM & -7.599658 & 0.0000 & -3.479367 & $\mathrm{I}(0)$ \\
\hline LSM & -9.246277 & 0.0000 & -3.479367 & $\mathrm{I}(0)$ \\
\hline LBLR & -6.150623 & 0.0000 & -3.480463 & $\mathrm{I}(0)$ \\
\hline
\end{tabular}

\section{Emperical Results}

\subsection{VAR approach of cointegration}

The objective of the cointegration test is to determine whether there is a long-run equilibrium among the variables. The result of the test will show if the variables are moving together in the long-run. The variables that are cointegrated showed that there exists a long-run equilibrium relationship between them. For this study, the Johansen and Juselius (1990) approach will be applied. The JJ approach will be based on the ratio test statistics which are $\lambda$ trace and $\lambda \max$. Based on the estimation and two statistics, Trace and Max eigen are calculated to test the presence of the cointegrating vector.

There are a few benefits of applying the cointegration test which is first; the test caters problems of non-stationary series, which may lead to spurious correlation. Second; the test allows any short-run dynamics of the data. Before conducting the cointegration test, it is in need to make sure that all the variables are in the same order. Cointegration relationship does not exist between the variables which are integrated in different orders. For instance, if $\mathrm{X}$ is $\mathrm{I}(1)$ and $\mathrm{Y}$ is $\mathrm{I}(2)$, then there will be no cointegration between them since they are not in the same order.

Vector AutoRegression (VAR) is one of the approaches to measure the long-run relationship between the variables. This model treats all the variables endogenously. In using the VAR approach, all variables need to be in $\mathrm{I}(0)$ condition. An important preliminary step in model building and impulse response function is the selection of the VAR lag order. This study will use some commonly used lag-order selection criteria to choose the lag order, such as the Akaike Information Criterion (AIC) and Schwarz Information Criterion (SC). Based on the Table 4, the lag order selection by criterion was lag 1 . Therefore, in this model lag 1 will be used in the modelling of the variables.
Table 4 Lag length order selection

\begin{tabular}{|c|c|c|c|c|c|}
\hline $\begin{array}{c}\text { La } \\
\mathrm{g}\end{array}$ & FPE & AIC & SC & HQ & LR \\
\hline 0 & 0.0022 & 5.2517 & 5.3866 & 5.3048 & \\
& 43 & 09 & 39 & 65 & NA \\
\hline 1 & & - & - & - & \\
& $3.89 \mathrm{e}-$ & 5.71090 & 5.03625 & 5.44512 & 676.29 \\
& $08^{*}$ & $2^{*}$ & $1^{*}$ & $3^{*}$ & $41^{*}$ \\
\hline 2 & & - & - & - & \\
& $4.19 \mathrm{e}-$ & 5.64433 & 4.42996 & 5.16593 & 23.8390 \\
& 08 & 9 & 7 & 7 & 2 \\
\hline
\end{tabular}

The model established from the VAR approach is as per below:

$\underline{\text { Model } 1}$

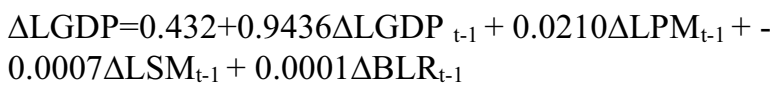

From the value of $\mathrm{R}^{2}$ the models have equations fit to the data. The $\mathrm{R}^{2}$ equal to 0.983 which showed that there is $98 \%$ changes in the GDP. The result of Darbin-Watson showed value close to 2 (1.836) in this equation which means there is no correlation in the model.

\section{$\underline{\text { Model } 2}$}

$$
\begin{aligned}
& \Delta \mathrm{LPM}=0.1500+0.0181 \Delta \mathrm{LGDP}_{\mathrm{t}-1}+0.9739 \Delta \mathrm{LPM}_{\mathrm{t}-1}+ \\
& 0.0051 \Delta \mathrm{LSM}_{\mathrm{t}-1}-0.0076 \Delta \mathrm{BLR}_{\mathrm{t}-1}
\end{aligned}
$$

From the value of $\mathrm{R}^{2}$ the models have equations fit to the data. The $\mathrm{R}^{2}$ equal to 0.999 which showed that there is $99 \%$ changes in the loan by primary mortgage market. The result of DarbinWatson showed value close to $2(1.938)$ in this equation which means there is no correlation in the model.

Model 3

$$
\begin{aligned}
& \Delta \mathrm{LSM}^{-}-14.626+2.7355 \Delta \mathrm{LGDP}_{\mathrm{t}-1}-1.3181 \Delta \mathrm{LPM}_{\mathrm{t}-1}+ \\
& 0.68012 \Delta \mathrm{LSM}_{\mathrm{t}-1}+0.0470 \Delta \mathrm{BLR}_{\mathrm{t}-1}
\end{aligned}
$$

From the value of $\mathrm{R}^{2}$ the models have equations fit to the data. The $\mathrm{R}^{2}$ equal to 0.857 which showed that there is $85 \%$ changes in the total loan sold to Cagamas. The result of Darbin-Watson showed value more than 2 (2.051) in this equation which means there is no correlation in the model.

\section{Model 4}

$\Delta \mathrm{BLR}=-9.6954+1.7836 \Delta \mathrm{LGDP}_{\mathrm{t}-1}-0.8239 \Delta \mathrm{LPM}_{\mathrm{t}-1}+-$ $0.0591 \Delta \mathrm{LSM}_{\mathrm{t}-1}+0.8408 \Delta \mathrm{BLR}_{\mathrm{t}-1}$ 
From the value of $\mathrm{R}^{2}$ the models have equations fit to the data. The $\mathrm{R}^{2}$ equal to 0.893 which showed that there is $89 \%$ changes in the GDP. The result of Darbin-Watson showed value not that close to $2(1.198)$ in this equation but it is acceptable which means there is no correlation in the model.

By applying the impulse response method, the relationship between those VAR models will be determined

\subsection{Impulse response}

Impulse response function will showed the responsiveness of the dependent variable to a shock of each variable in the VAR model. This means that, if a shock is applied to one of the variable while the other equations are constant, it will affect the VAR system over the time. One of the rules in implementing the impulse response function, the order of the variable need to be correct since different order of variable will present a different output. Therefore, the dependent variable should be at the beginning of the list followed by the independent variable. The impulse response
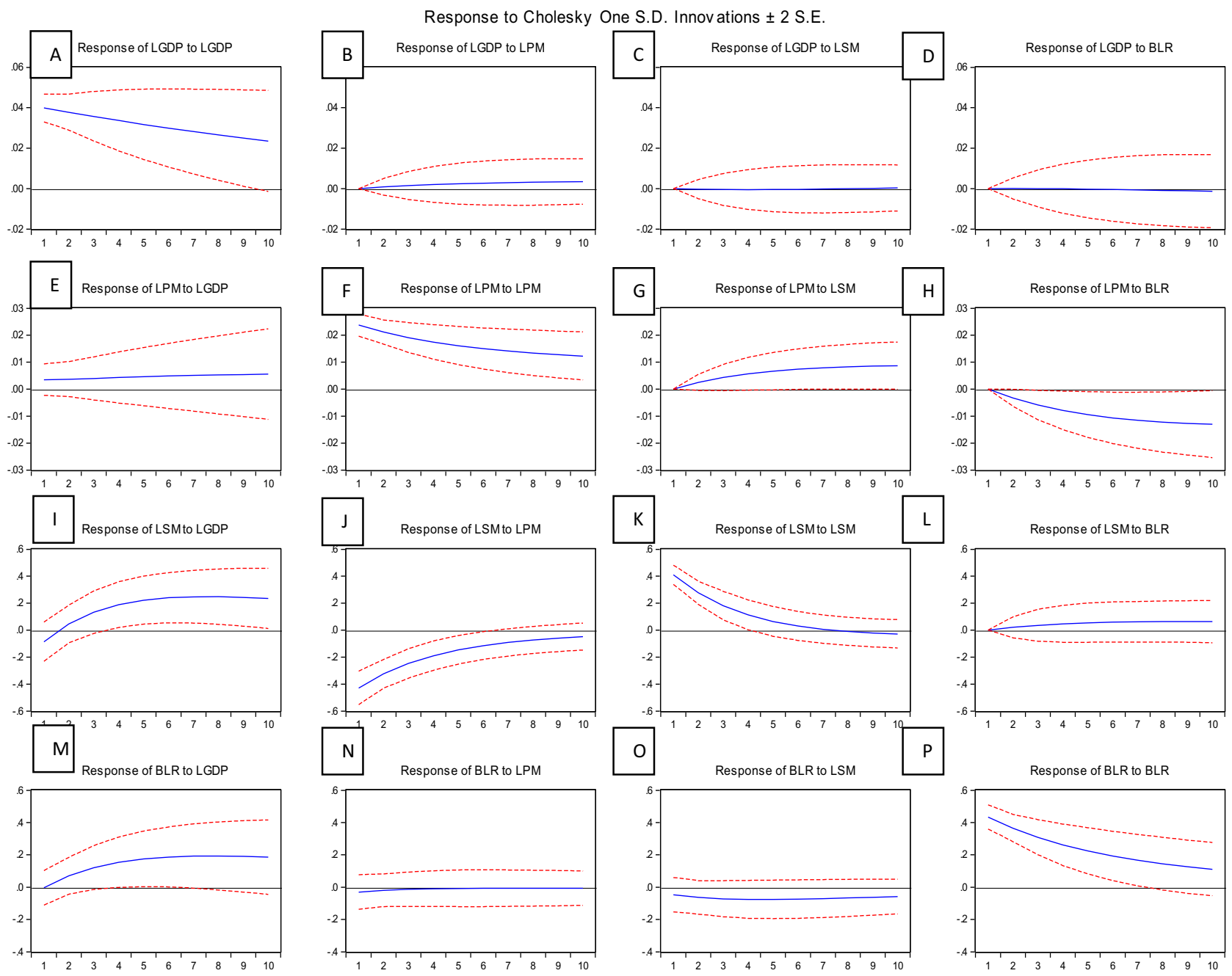

Figure 1 Impulse responses between macroeconomic and housing finance variabl

Primary Mortgage Market responds positively and significantly to the GDP (Figure 2E). When the economy is good and there are increases in the GDP, there are more funds available for the banking institution to extend loan. Hence, it will increase the number of housing loans extended by the banks to the customers. The bank loan respond positively to the real output, which is in line with the previous study by
Ibrahim (2006) and Mansor and Mohamed (2012). In contrast, there is no significant effect of primary mortgage market to the GDP (Figure 2B).

Figure $2 \mathrm{G}$ and $2 \mathrm{~J}$ shows the impulse respond between two housing finance submarkets, primary mortgage market and secondary mortgage market. Secondary mortgage market responds positively to the primary mortgage market (Figure 
$2 \mathrm{G})$. When there is increase in the number of housing loans taken by the house buyers, the banks will increase the volume of housing loans sold to Cagamas. Although in reverse, primary mortgage market responds negatively to the secondary mortgage market (Figure $2 \mathrm{~J}$ ).

Figure $2 \mathrm{C}$ and $2 \mathrm{D}$ shows that there is no significant response of both the secondary mortgage market and the interest rate to real GDP output. Primary Mortgage Market reacts negatively to the lending rate (Figure $2 \mathrm{H}$ ). It showed that the bank lending rate reacts negatively with the interest rate charged to the customer. More housing loans extended by the primary mortgage market consequently will reduce the base lending rate. The similar response seen in the lending rate which acts negatively with the Secondary Mortgage Market (Figure 2O). When there is a shock in the interest rate; which happened during the financial crisis, there will be more housing loans sold to the secondary mortgage market as a measure by the government to increase liquidity in banking institutions.

\section{Conclusion}

The main objective of this analysis to determine the interrelationship between the macroeconomic and housing finance variable. The objective was achieved by using time series technique of Vector Autoregression (VAR) method to identify the relationship between the macroeconomic variable (GDP and BLR) and housing finance variable (total loan by primary mortgage market and secondary mortgage market). The cointegration test showed that there is a long run relationship between the variable.

The impulse response function showed that there is positive response between the GDP and primary mortgage market. When there are increases in the GDP, there are more funds available for the banking institution to extend loan Apart from that, when there is a shock in the interest rate; which happened during the financial crisis, there will be more housing loans sold to the secondary mortgage market as a measure by the government to increase liquidity in banking institutions. As a conclusion, there is presence of relationship between the variable which change in one variable will affect the other variable in the long run.

\section{References}

1. Bank Negara Malaysia (Various Issues) Annual Report (Kuala Lumpur: Bank Negara Malaysia).

2. Bank Negara Malaysia (Various Issues) Monthly Statistical Bulletin (Kuala Lumpur: Bank Negara Malaysia).

3. Bank Negara Malaysia (Various Issues) Quarterly Bulletin (Kuala Lumpur: Bank Negara Malaysia).
4. Chung, T. (2014). Promoting a Secondary Mortgage Market and Debt Capital Market. HOUSING THE NATION: Policies, Issues and Prospects ISBN, 978-983.

5. Department of Statistics (2012), Malaysian Economy in Brief 2012.

6. Garnett, D. (2005). Housing finance. Chartered Institute of Housing/Housing Studies Association.

7. Gerlach, S., Peng, W., (2005). Bank lending and property prices in Hong Kong. Journal of Banking and Finance 29, 461-481.

8. Granger, C. W. (1969). Investigating causal relations by econometric models and cross-spectral methods. Econometrica: Journal of the Econometric Society, 424-438.

9. Greef and Haas, (2000). Greef, I.J.M. De, Haas, R.T.A De (2000), Housing Price, Bank Lending and Monetary Policy, Paper presented At The Financial Structure, Bank Behaviour and Monetary Policy In The EMU Conference, October 2000, Groningen.

10. Hilbers, P., Qin Lei And Lisbeth, Z. (2001), Real Estate Market Developments And Financial Sector Soundness, IMF Working Paper No. 01/129, Washington : International Monetary Fund.

11. Ibrahim, M.H.,(2006) Stock prices and bank loan dynamics in a developing country: the case of Malaysia. Journal of Applied Economics 9 (1), 71-89

12. Johansen, S., Juselius, K., (1990). Maximum likelihood estimation and inference on cointegration - with application to the demand for money. Oxford Bulletin of Economics and Statistics 52, 169-210

13. Koop, G (2008) Analysis of Economic Data $-3^{\text {rd }}$ Edition, John Wiley \& Sons, Chichester, UK.

14. Lea, M.J. (2000) The Role of the Primary Mortgage Market In The Development Of A Successful Secondary Mortgage Market, Best Practice Series, Inter-American Development Bank

15. Mansor H. I., Mohamed E. S.,(2012) Bank lending, macroeconomic conditions and financial uncertainty: Evidence from Malaysia, Review of Development Finance, Volume 2, Issues 3-4, Pages 156-164, ISSN 1879-9337

16. Said, R., Adair, A., McGreal, S., \& Majid, R. (2014). Inter-relationship between the housing market and housing finance system: evidence from Malaysia.International Journal of Strategic Property Management, 18(2), 138-150.

17. Sufian, F. (2004). The efficiency effects of bank mergers and acquisitions in a developing economy: Evidence from Malaysia. International Journal of Applied Econometrics and Quantitative Studies, 1(4), 53-74.

18. Tiwari, P. (2000), "Housing Demand In Tokyo", International Real Estate Review, Vol.3, No.1\

19. Veronica C. W, Francis E. W.(2008) Markets and housing finance, Journal of Housing Economics, Volume 17, Issue 3, Pages 239-251, ISSN 1051-1377, 